\title{
PLASMINOGEN MODULATES FORMATION AND RELEASE OF PLATELET ANGIOGENIC REGULATORS
}

\author{
A. A. TYKHOMYROV , D. D. ZHERNOSEKOV, T. V. GRINENKO \\ Palladin Institute of Biochemistry, National Academy of Sciences of Ukraine, Kyiv; \\ 凶e-mail: artem_tykhomyrov@ukr.net
}

Received: 19 July 2019; Accepted: 29 November 2019

\begin{abstract}
Platelets store, produce and release a variety of angiogenesis regulators, which can contribute to both normal tissue repair and angiopathy-associated pathologies. Plasminogen has been earlier shown to regulate some platelet functions, but if it is able to modulate angiogenic capacities of platelets is still poorly studied. Thus, the aim of the present study was to evaluate the effects of different plasminogen forms on the formation and secretion of angiogenic protein regulators by platelets. Human washed platelets were obtained by gelfiltration on Sepharose-2B. The levels of P-selectin (CD-62P) exposed on the plasma membrane of untreated and activated platelets was monitored by flow cytometry. Secretion of platelet-derived vascular endothelial growth factor (VEGF) as well as plasminogen fragmentation and angiostatin formation by intact platelets and platelet plasma membranes were analyzed by immunoblotting. It was shown that thrombin or collagen exposure resulted in enhanced P-selectin surface expression by platelets, while Lys-form of plasminogen reduced agonist-induced platelet secretion. Lys-plasminogen, but not Glu-form, inhibited agonist-induced VEGF release from platelets. Activation of platelets significantly accelerated plasminogen cleavage and angiostatin formation. Anti-actin antibodies inhibited plasminogen fragmentation during incubation with platelet plasma membranes indicating surface-exposed actin participation in plasminogen conversion to angiostatins. The present study uncovers a novel function of plasminogen to limit angiogenic potential of platelets via angiostatin formation and inhibition of VEGF secretion.
\end{abstract}

Ke y w o rds: plasminogen, platelets, angiogenesis, vascular endothelial growth factor (VEGF), angiostatins.

$\mathrm{P}$ latelets are the first cells accumulated at the site of vessel injury and have been primarily recognized to play a pivotal role in haemostasis and thrombosis. However, it is currently accepted that platelets also regulate a number of non-haemostatic processes, including modulation of immune response, cell migration and angiogenesis. It becomes possible because platelets store and form both stimulators and inhibitors of angiogenesis, which are contained mainly in their $\alpha$-granules and released upon activation. Platelet-released factors contribute to a wide range of pathophysiological events, such as inflammation, tumor growth, proliferative retinopathy, atherosclerosis, and autoimmune diseases [1]. For example, vascular endothelial growth factor (VEGF) is segregated in the specialized $\alpha$-granules in large quantities and deliberated during platelet secretion in response to the action of agonists, such as collagen, thrombin, or ADP. Platelet-derived VEGF may play a protective role to induce reparative angiogenesis as a phase of wound healing or may be involved in pathological processes, first of all cancers [2].

Although the proangiogenic effects of platelets have been well-documented, less is known about their inhibitory effects on angiogenesis. In terms of 'angiogenic balance', angiostatin is considered as one of the most important VEGF counteracting regulators. Angiostatin comprises a range of proteolytic fragments of plasminogen/plasmin, containing various number of kringle domains, mainly the first 3 to 5 subunits (K1-3, K1-4, K1-4.5, K1-5). Angiostatin polypeptides specifically inhibit proliferation and migration of endothelial cells, induce apoptosis, suppress vessel tube formation, and capillary sprouting,

(C) 2020 Tykhomyrov A. A. et al. This is an open-access article distributed under the terms of the Creative Commons Attribution License, which permits unrestricted use, distribution, and reproduction in any medium, provided the original author and source are credited. 
thus reducing tumor angiogenesis and metastasis [3]. Initially, angiostatin has been discovered to be produced by cancer cells, pro-inflammatory cells macrophages and neutrophils [4]. Platelets have been recently shown to produce angiostatins, but the dependence of their generation upon the functional state of platelets remains controversial [5]. Activation of platelets can result in exposition of novel sites for plasminogen binding and likely is needed for angiostatin generation. Among them, the particular attention is paid to the surface-exposed actin, a cytoskeletal protein of microfilaments, which has been demonstrated on the outer surface of various normal and transformed cells [6]. It was shown that platelets are able to expose actin on their surface in an activation-dependent manner [7, 8]. Moreover, we have provided experimental evidence that surface-exposed actin is involved in plasminogen binding to platelet plasma membrane [9]. However, if this binding has functional significance remains unexplored. In the previous experiments, we have established that partially truncated plasminogen molecule (Lys-form) interferes agonist-induced actin cytoskeleton rearrangements [10] and inhibits $\alpha$-granule release [11]. Surface-exposed actin plays a crucial role not only in plasminogen binding, but also in its conversion into angiostatins on the outer membrane of different cell lines, such as PC-3 prostate, HT1080 fibrosarcoma, and MDA-MB231 [12]. Nevertheless, the precise mechanism of angiostatin formation by platelets and putative role of surfaceexposed actin remain unclear.

In this study, we investigated if plasminogen affects release of VEGF and formation of angiostatin by human platelets and whether these effects are dependent on the functional state of platelets. Also, we aimed to elucidate whether surface-expressed actin is responsible, at least partially, for angiostatin generation by platelets.

\section{Materials and Methods}

Chemicals and antibodies. All chemical used were of analytical reagent grade quality and purchased from Sigma-Aldrich (USA), except for those specified in the text. Mouse monoclonal anti-VEGF antibody was obtained from Abcam (USA, cat. no. ab1316), monoclonal phycoerythrin (PE)-conjugated anti-P-selectin (CD-62P) antibody was purchased from Acris Antibodies, Inc. (USA, cat. no. AM26020RP-N). Anti-plasminogen/angiostatin antibodies were produced in rabbits and characterized as described elsewhere [13]. Goat anti-rabbit IgG (Sigma-Aldrich, A0545) and anti-mouse IgG (Abcam, USA, cat. no. ab6789) secondary HPR-conjugated antibodies were used.

Platelets. Washed platelets were obtained from human platelet-rich plasma by gel-filtration on Sepharose $2 \mathrm{~B}$ as described elsewhere [9]. Informed consent was obtained from all donors $(n=3)$ in accordance with the Declaration of Helsinki, research protocols were approved by the Ethical Committee of Palladin Institute of Biochemistry of NASU ( $3^{\text {rd }}$ November, 2014, protocol No. 10).

To assess platelet viability and functional activity, agonist-induced platelet aggregation was monitored by optical aggregometry (aggregometer Solar AT-02, Republic of Belarus), as described earlier [9]. All assays were performed within 60-80 min after platelet collection.

$P$-selectin exposition (flow cytometry assay). Flow cytometry assay was used to measure a surface expression of $\alpha$-granule marker, P-selectin, on the platelet surface. Platelets $\left(2.5 \times 10^{6}\right.$ per sample $)$ resuspended in HEPES buffer were activated by thrombin $(1.0 \mathrm{NIH}$ unit $/ \mathrm{ml})$ or collagen $(1.25 \mathrm{mg} / \mathrm{ml})$ for $5 \mathrm{~min}$ at $37^{\circ} \mathrm{C}$. To study the effects of plasminogen on platelet secretion, cells were preincubated with Glu- or Lys-plasminogen $(1.2 \mu \mathrm{M})$ for $3 \mathrm{~min}$ with or without following activation by agonists. Non-stimulated platelets were treated in the same manner, except physiological saline was added as a vehicle (resting control). After treatment, $20 \mu 1$ of PE-conjugated anti-P-selectin antibodies were added to platelet suspensions and incubated for $30 \mathrm{~min}$ according to manufacturer recommendations. The measurement of the intensity of specific PE fluorescence was monitored in each group of platelets with the use of Coulter Epics XL device (Beckman Coulter, USA) via FL3 channel as described earlier [11].

$V E G F$ secretion. To study effects of plasminogen on VEGF release, washed platelets $\left(1.52 \times 10^{8}\right.$ per sample) were resuspended in HEPES buffer and treated as described before, with the exception of thrombin (0.1 and $1.0 \mathrm{NIH}$ units $/ \mathrm{ml})$ and collagen $(0.125$ and $1.25 \mathrm{mg} / \mathrm{ml})$ concentrations. After treatment, platelet pellets and releasates were separated by centrifugation $\left(1,500 \mathrm{~g}\right.$ for $15 \mathrm{~min}$ at $\left.15^{\circ} \mathrm{C}\right)$. Sedimented platelets were solubilized on ice with the non-reducing SDS-containing electrophoretic buffer, freshly supplemented with the protease and phosphatase inhibitor cocktail PPC 1010, boiled for 5 min and stored at $-20^{\circ} \mathrm{C}$ for further analysis. 
Platelet releasate and lysate samples were subjected to $12 \%$ SDS-PAGE and transferred onto nitrocellulose membranes by electroblot. After blocking in 5\% non-fat dry milk, blots were probed with the primary antibodies against VEGF, 1:1000 diluted in $5 \%$ non-fat milk PBS, containing $0.1 \%$ Tween-20 (PBST) overnight at $4{ }^{\circ} \mathrm{C}$. Then, membranes were washed five times with PBST and incubated with appropriate HRP-conjugated secondary antibodies for 90 min at $37^{\circ} \mathrm{C}$. After washing in PBST, blots were developed with the use of the chemiluminescence HPR substrate, signals were visualized and digitized by TotalLab TL120 software (USA).

Angiostatin generation. Platelets $\left(2 \times 10^{8}\right)$ treated by Lys-plasminogen alone and platelets preincubated with Lys-plasminogen and then aggregated with thrombin $(1.0 \mathrm{NIH}$ units $/ \mathrm{ml})$ or collagen $(1.25 \mathrm{mg}$ / $\mathrm{ml})$ as described above were separated from releasates by centrifugation at $1,800 \mathrm{~g}$ for $10 \mathrm{~min}$ at room temperature. Releasates were collected into plastic tubes and mixed with the SDS-containing non-reducing electrophoretic buffer. Platelet pellets were washed twice by $50 \mathrm{mM}$ Tris- $\mathrm{HCl}$ saline buffer (TBS), $\mathrm{pH}$ 7.4, by centrifugation and lysed in the electrophoretic buffer. Samples of platelet releasates and lysates were separated by $5 \div 15 \%$ SDS-PAGE and transferred onto nitrocellulose membranes for further Western blot analysis.

In order to verify if membrane-associated generation of angiostatin depends on activation state, washed platelets $\left(1.3 \times 10^{8}\right)$ were activated by the addition of thrombin (1.0 NIH units/ml), then aggregation was monitored for $5 \mathrm{~min}$. After aggregation, platelet pellets were separated from the releasates using centrifugation (1,800 g for $10 \mathrm{~min})$. After sedimentation, unstimulated and thrombin-stimulated platelets were lyzed with ice-cold hypotonic saline $(0.2 \% \mathrm{NaCl})$ at $4{ }^{\circ} \mathrm{C}$ with constant stirring as described previously [14]. Membranes were separated by centrifugation at 13,000 for $10 \mathrm{~min}$ at $4{ }^{\circ} \mathrm{C}$, and isolated membranes were washed twice and resuspended in TBS. Membranes of resting and activated platelets were incubated with Glu-plasminogen in physiological concentration $(1.45 \mu \mathrm{M})$ during $3 \mathrm{~h}$ at $37^{\circ} \mathrm{C}$. Then, suspensions were mixed with the electrophoretic buffer and loaded onto 10\% SDS-PAGE in the volumes containing $2 \mu \mathrm{g}$ of plasminogen per lane.

In parallel, we established if surface-exposed actin may play a role in angiostatin generation by the membranes of activated platelets. Prior to the addi- tion of plasminogen (for $60 \mathrm{~min}$ at $37^{\circ} \mathrm{C}$ ), anti-actin antibodies $(8 \mu \mathrm{g} / \mathrm{ml})$ were added to the membrane fraction of thrombin-stimulated platelets and incubated for $5 \mathrm{~min}$. Other aliquot of platelet membranes was incubated with the same amount of non-immune rabbit $\operatorname{IgG}$ and served as a control. For experiments performed with the serine protease inhibitor para-nitrophenyl guanidine benzoate (p-NPGB) $\left(5 \times 10^{-4} \mathrm{M}\right)$, platelet membranes were incubated with plasminogen for $60 \mathrm{~min}$ at $37^{\circ} \mathrm{C}$. After incubation, membrane suspensions were mixed with electrophoretic buffer and blotted. For detection of proteolytic activity impurities that might contribute to plasminogen degradation to produce false-positive result, rabbit IgG, anti-actin IgG, collagen, and thrombin were incubated with Glu-plasminogen and subjected to immunochemical analysis. Western blots of plasminogen/angiostatins were performed as described above with the use of primary rabbit anti-K1-3 antibodies followed by incubation with the appropriate secondary HRP-conjugated antibodies. Specific immunostaining of plasminogen/angiostatins was developed in $0.05 \% 3,3^{\prime}$-diaminobenzidine solution in $50 \mathrm{mM}$ Tris- $\mathrm{HCl}$ ( $\mathrm{pH} 7.4$ ), with the addition of $0.01 \%$ hydrogen peroxide.

Statistical analysis. The results were expressed as medians for non-normal distributed samples. The statistics were performed with the use of MannWhitney U-test. Differences between parameters studied in each group were considered to be significant at $P$ less than 0.05 .

\section{Results and Discussion}

Lys-plasminogen affects P-selectin exposition. $\mathrm{P}$-selectin, or CD-62P, is a platelet $\alpha$-granule specific protein, which mediates platelet-neutrophil adhesion. During stimulation, P-selectin appears on the cell surface and thus serves as a marker of platelet activation [15]. P-selectin flow cytometric measurement data presented as fluorescence intensity curves are depicted in Fig. 1. Unlike Glu-plasminogen, Lysform of proenzyme slightly increased the level of $\mathrm{CD}-62 \mathrm{P}$ on the platelet surface. The fluorescence intensities of platelets treated with thrombin or collagen showed a marked increase with stimulation. It is worth noting that pretreatment of platelets with Lysplasminogen affected thrombin-activated platelet secretion in greater extent than collagen-stimulated $\alpha$-granule release.

Effects of plasminogen on VEGF secretion by platelets. The ratio of [VEGF releasate]/[VEGF 
$A$
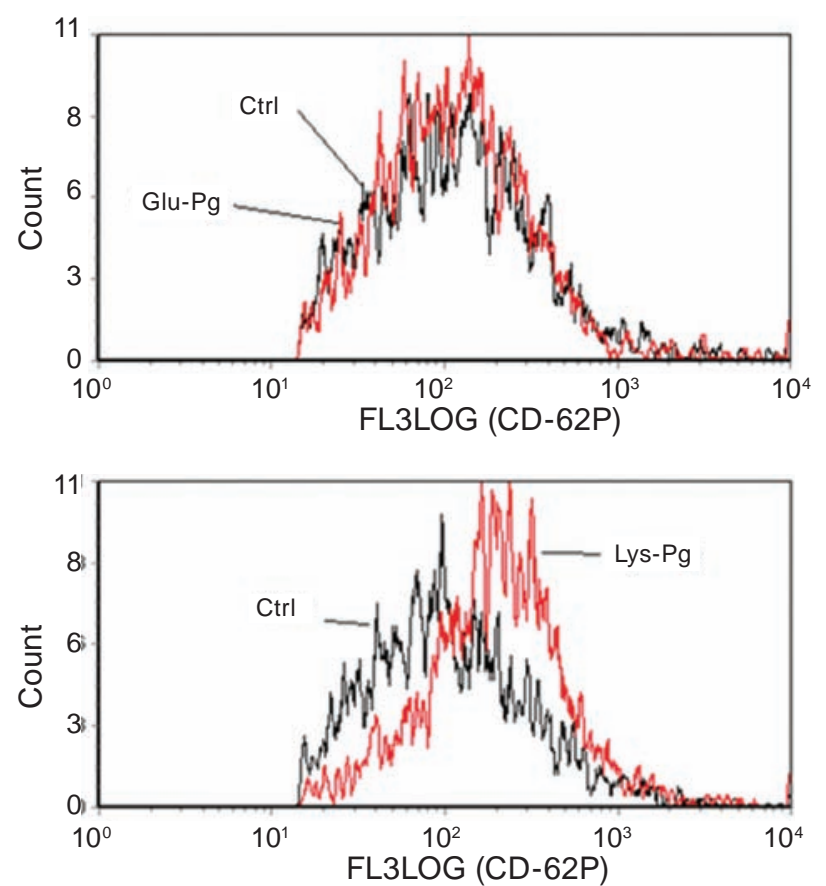

B
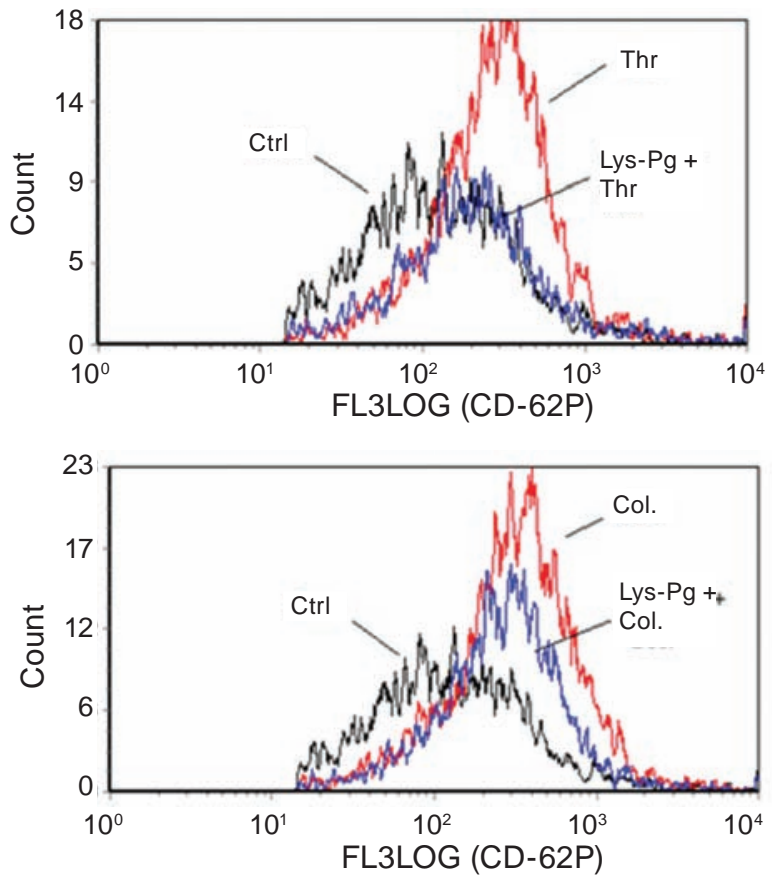

Fig. 1. Effects of plasminogen on P-selectin surface expression by resting (A) and agonist-stimulated (B) platelets. Notes: Ctrl-control (resting platelets), Pg-plasminogen, $\mathrm{Thr}$ - thrombin, Col-collagen

lysate] was calculated to evaluate effects of plasminogen on growth factor release. As seen in Fig. 2, Western blot analysis of platelet-derived VEGF showed that two forms of plasminogen differently affect VEGF secretion. In the samples of resting platelets, essentially no VEGF was released during incubation period. Incubation of platelets with studied proteins resulted in partial deliberation of VEGF from cells to releasates. Only a minor portion of VEGF was released during incubation with Gluplasminogen, while Lys-form significantly enhanced VEGF exocytosis. Growth factor release from platelets greatly depends on the activator dose and nature, with the more potent of the two agonists, thrombin. Thrombin $0.1 \mathrm{NIH}$ units/ml induced partial secretion of VEGF from platelets, while the greater thrombin concentration induced complete VEGF deliberation, so that $40 \mathrm{kDa}$ VEGF band appeared to be almost undetectable in platelet lysates. Collagen induced weaker VEGF release, when used in submaximal concentrations $(0.125$ or $1.25 \mathrm{mg} / \mathrm{ml})$. It is important to note that pretreatment of platelets with Lysplasminogen significantly reduced collagen-induced VEGF release and, to the greater extent, thrombinevoked growth factor secretion. These observations are in remarkable agreement with the data of P-se- lectin measurements suggesting that plasminogen can modulate exocytosis of platelet $\alpha$-granules. Different amounts of VEGF fragments $(\sim 20 \mathrm{kDa})$ were detected by western blot in the samples of platelets treated with plasminogen alone or followed by agonist action. Truncated VEGF polypeptides likely result from limited proteolysis of the native cytokine molecules.

Platelets mediate Lys-plasminogen-angiostatin conversion. In order to determine the extent to which platelets promote proteolytical cleavage of Lys-plasminogen directed to the angiostatin appearance and to verify if angiostatin generation depends on the functional state of platelets, we separated incubation medium and cells after treatment procedure. As shown in Fig. 3, trace amounts of angiostatin-like polypeptides were found in lysates and releasates after incubation of platelets with Lys-plasminogen alone. However, platelets appeared to be able to produce abundance of plasminogen fragments after stimulation by two agonists. The major truncated products had a mol. weight $\sim 45-50 \mathrm{kDa}$ and thus might correspond to angiostatins K1-4 and K1-4.5. The vast amount of angiostatin-like polypeptides is released and accumulated in the incubation medium. Activation of platelets with collagen resulted in the 

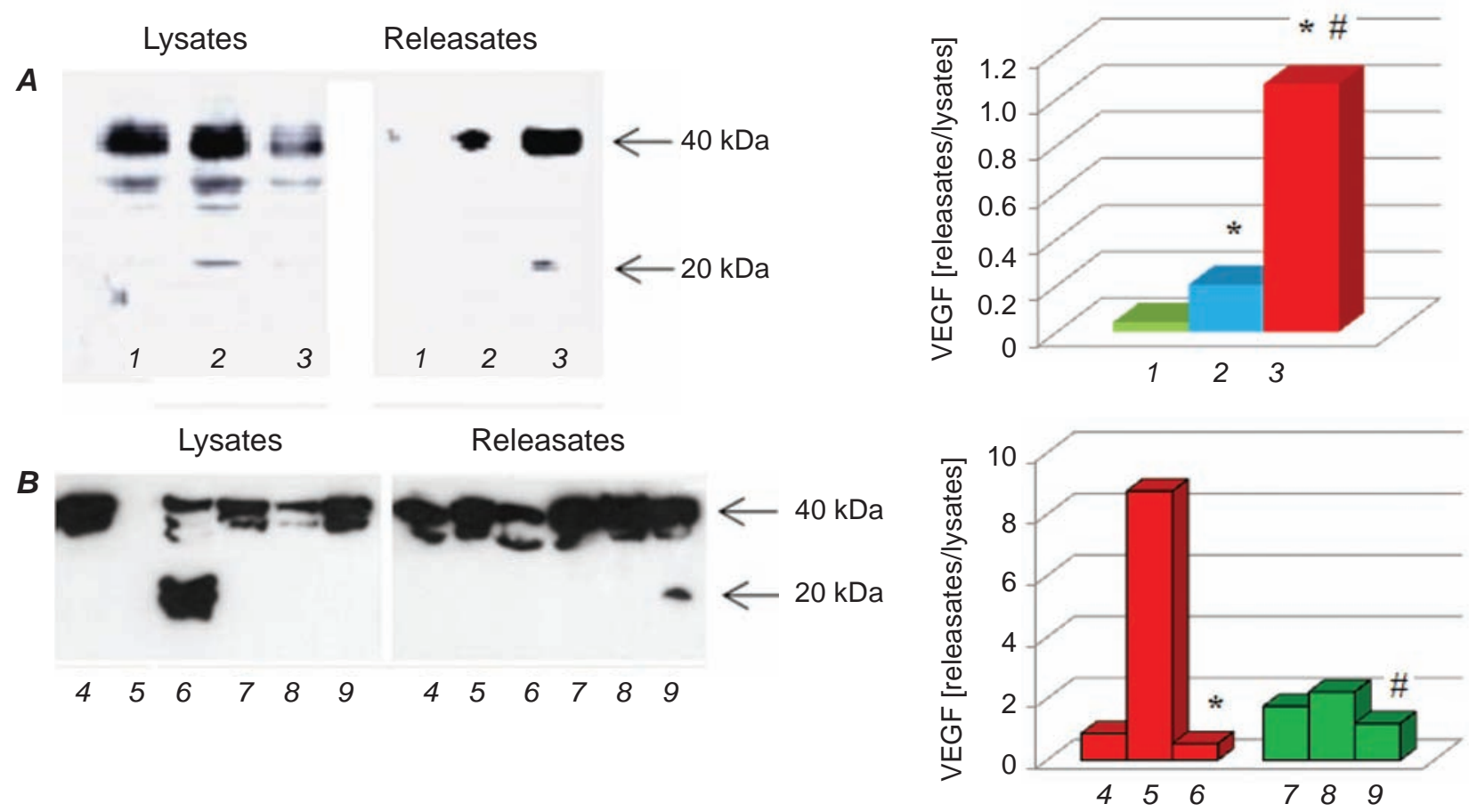

Fig. 2. Effects of plasminogen on the VEGF secretion by resting platelets (A) and agonist-stimulated platelets (B): 1 - control (resting platelets), 2 - Glu-Pg, 3-Lys-Pg, $4-\mathrm{Thr}(0.1 \mathrm{NIH}$ units $/ \mathrm{ml}), 5-\mathrm{Thr}(1.0 \mathrm{NIH}$ units $/ \mathrm{ml}), 6-\mathrm{Lys}-\mathrm{Pg}+\mathrm{Thr}(1.0 \mathrm{NIH}$ units $/ \mathrm{ml}), 7-\mathrm{Col}(0.125 \mathrm{mg} / \mathrm{ml}), 8-\mathrm{Col}(1.25 \mathrm{mg} / \mathrm{ml}), 9-\mathrm{Lys}-\mathrm{Pg}+\mathrm{Col}$ $(1.25 \mathrm{mg} / \mathrm{ml})$. Notes: $* P<0.001$ vs. Thr $(1.0 \mathrm{NIH}$ units $/ \mathrm{ml})$, $\# P<0.05 \mathrm{vs} . \mathrm{Col}(1.25 \mathrm{mg} / \mathrm{ml})$

generation of minor protein products of lower mol. weights $(38-25 \mathrm{kDa})$, which were developed weakly in the samples of thrombin-stimulated cells.

Plasminogen fragmentation is a surfacerelated process. To test the potential significance of cell membranes for plasminogen conversion into angiostatins, native proenzyme form was incubated separately with whole cells and the cell membrane fraction. The reactions were subjected to immunoblotting to probe for the presence of angiostatin-like products (Fig. 4, A).

Like Lys-plasminogen, Glu-form was more actively cleaved by activated platelets than resting cells. Loss of plasminogen was observed after $3 \mathrm{~h}$ of incubation with thrombin-activated platelets, and the majority of different angiostatin species migrated in SDS-PAGE at the mol. weight range of 50-25 kDa. During more prolonged incubation of Glu-plasminogen with platelets, the degree of plasminogen to angiostatin conversion increased over the next $13 \mathrm{~h}$. Moreover, in the case of activated platelets, $16 \mathrm{~h}$ incubation resulted in complete disappearance of plasminogen and further degradation of angiostatin-like products. A similar profile of plasminogen degradation in the presence of cell membranes of activated platelets was observed (Fig. 4, B) that confirms plasminogen activation by platelets and angiostatin-generating activity to be rather surfacerelated events.

Surface-exposed actin is involved in angiostatin production by platelets. In order to verify if surface-exposed actin makes a contribution, if any, to plasminogen to angiostatins conversion, intact or anti-actin antibody pretreated membranes of activated platelets were incubated with Glu-plasminogen for $1 \mathrm{~h}$. As shown in Fig. 5, A, an anti-actin antibody did not completely inhibit the generation of angiostatin by the cell membrane fraction, but significantly reduced plasminogen cleavage (Fig. 5, B). This result confirms the hypothesis that actin on the outer surface of the platelet membrane may serve as one of the site for angiostatin generation from plasminogen.

To confirm the catalytic role of plasmin in angiostatin generation, we incubated plasminogen with the membrane fraction of activated platelets in the presence of plasmin inhibitor, $\mathrm{p}$-NPGB. On the basis of immunoblot of resultant suspension (Fig. 5, A), membranes treated with inhibitor appeared to be unable to effectively cleave plasminogen. This inhibitory study indicates that plasmin is the essential 

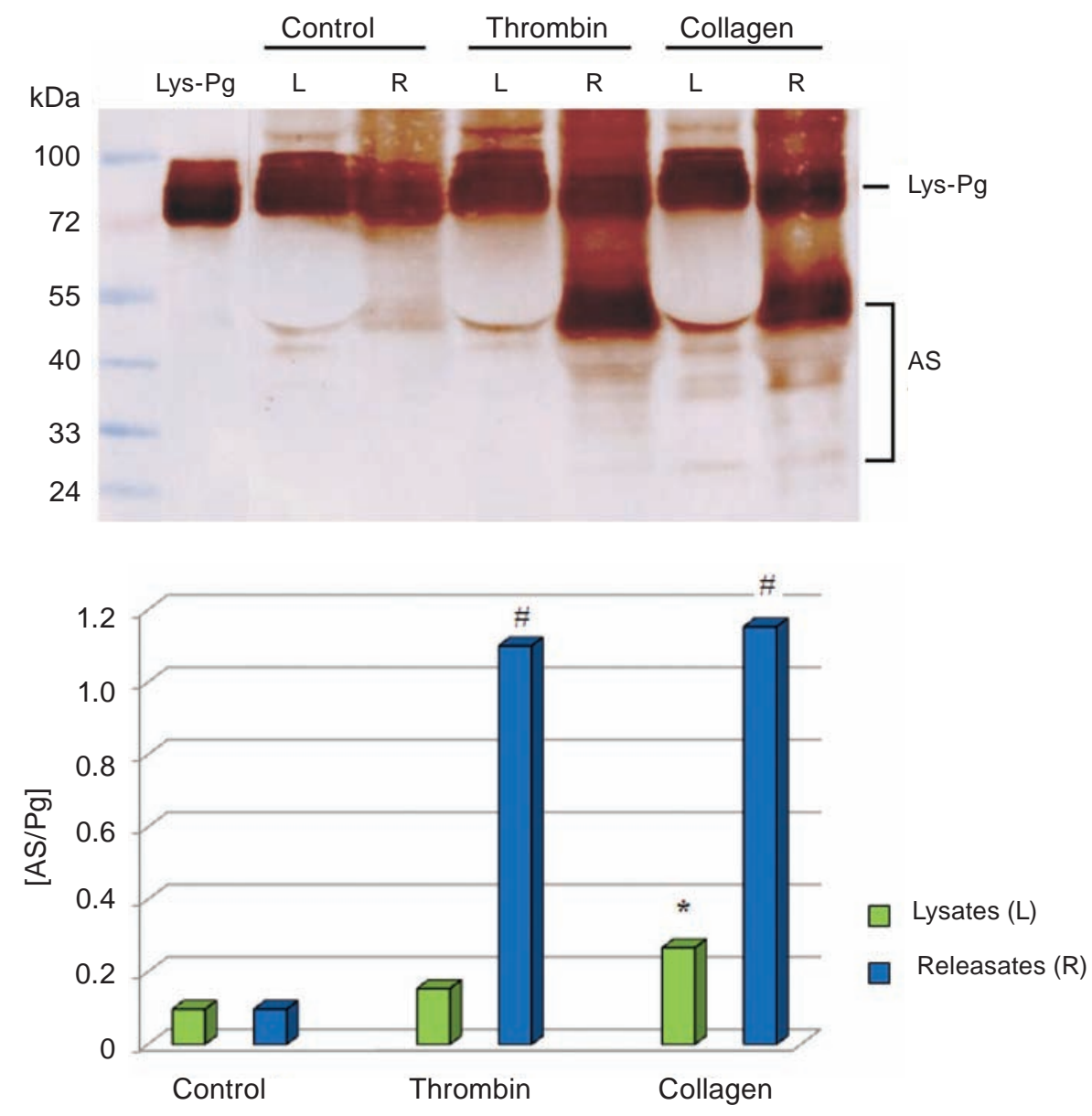

Fig. 3. Detection of angiostatins in lysates $(L)$ and releasates of resting (control) and stimulated platelets after incubation with Lys-plasminogen $(1.2 \mu M)$ for 8 min. Notes: $* P<0.05$ vs. Control, $\# P<0.001$ vs. control

A

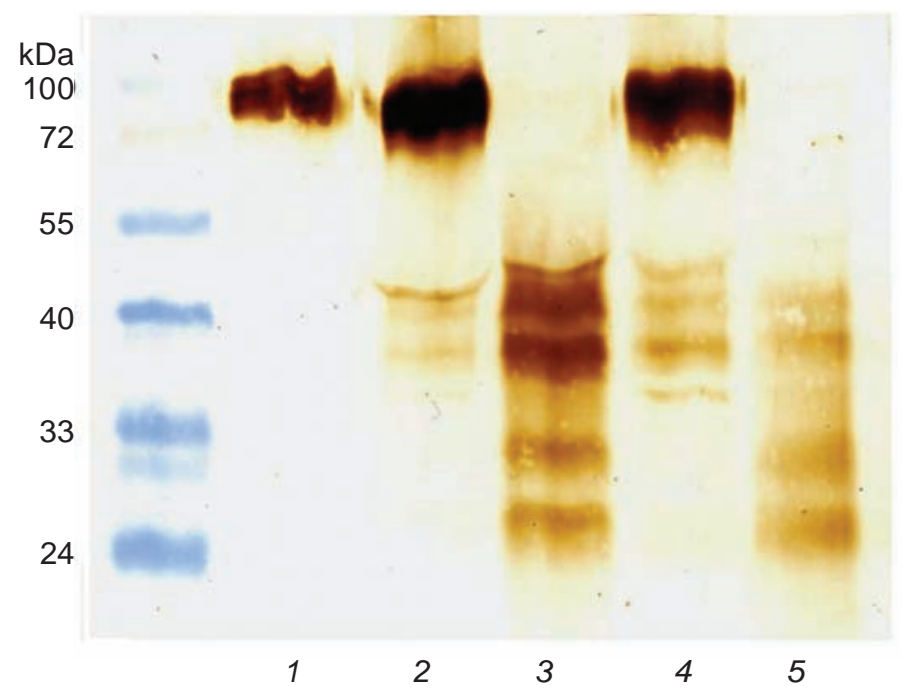

B

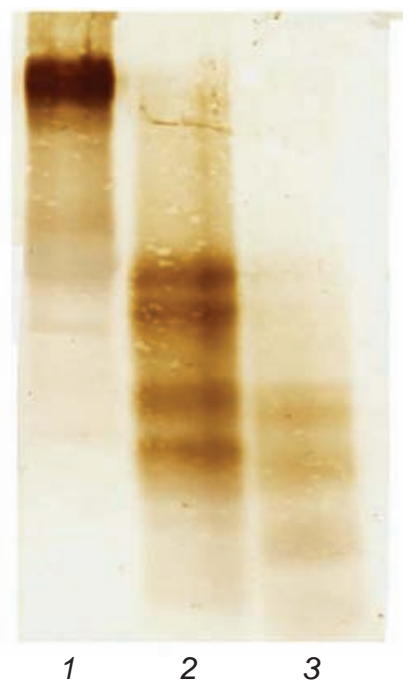

Fig. 4. Fragmentation of Glu-plasminogen by the whole platelets (A): 1 -Glu-Pg; 2 - intact platelets, $3 \mathrm{~h}$ incubation; 3 -Thr-stimulated platelets, 3 h incubation; 4 - intact platelets, 16 h incubation; 5 -Thr-stimulated platelets, $16 \mathrm{~h}$ incubation) and in the presence of membrane fraction of Thr-stimulated platelets (B): 1 -initial point; 2 - 3 h incubation; 3 - 16 h incubation 


\section{$\boldsymbol{A}$}

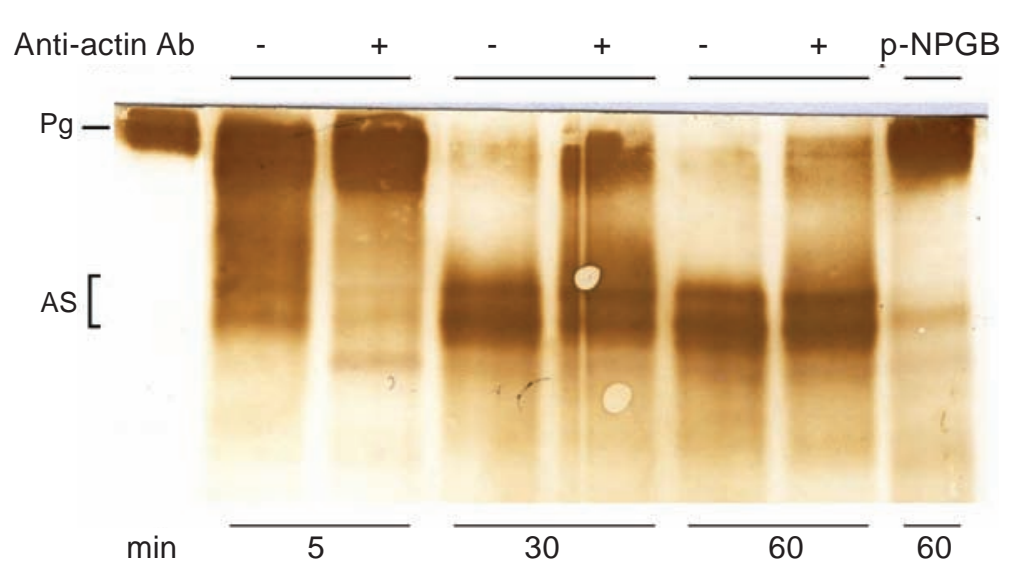

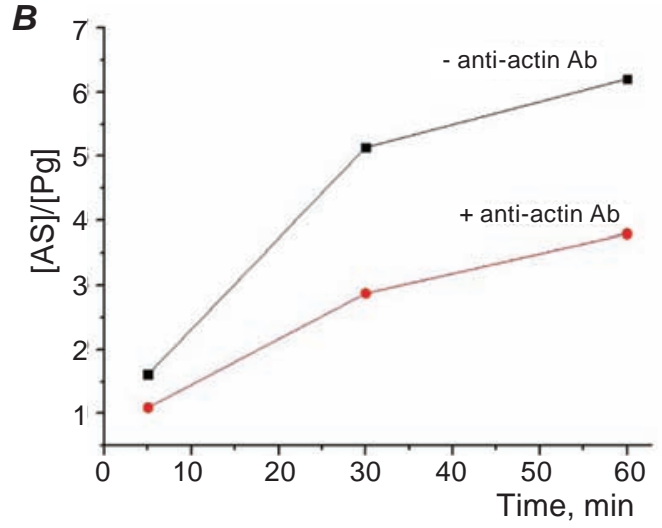

C

Thr IgG anti-actin Col

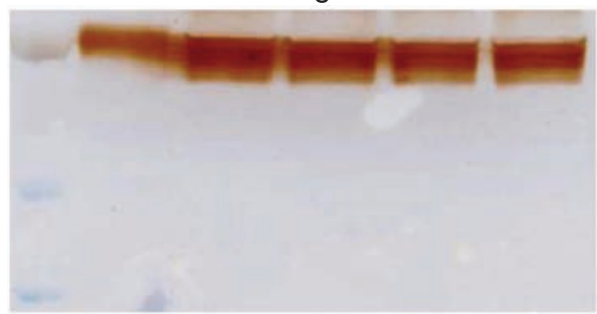

Fig. 5. Effects of actin blockage on plasminogen fragmentation and angiostatin formation in the presence of membranes of thrombin-stimulated platelets: $\boldsymbol{A}$ - immunoblotting of platelet membrane samples incubated with Glu-plasminogen without (-) or with (+) pretreatment with anti-actin antibodies; $\boldsymbol{B}$ - profile of angiostatin generation estimated by the value $[A S] /[P g] ; \boldsymbol{C}$ - control immunoblot on non-specific plasminogen proteolysis during incubation with thrombin (Thr), collagen (Col), non-immune IgG, or anti-actin antibodies

proteinase, which provides angiostatin formation, but other proteinases could also be involved in this process, but to lesser extent. As seen in Fig. 5, $C$, any of protein reagents used in the study (thrombin, collagen, anti-actin antibody, non-specific $\operatorname{IgG}$ ) did not contain proteolytic impurities, which might digest plasminogen.

Platelets have been reported to participate in maintaining angiogenic balance in health and injury [16]. Pro- and antiangiogenic mediators are segregated in different types of platelet $\alpha$-granules and deliberated differentially to provide precise temporal regulation of angiogenesis in a damaged tissue [17]. Different platelet-derived proteinases are involved in VEGF processing and metabolism. Plasmin, MMPs, uPA, elastase and tissue kallikrein have distinct effects on VEGF, including cleavage, activation, liberation from extracellular stores, and degradation [18]. Based on the present flow cytometry data on platelet degranulation (P-selectin detection), we expected a release of angiogenesis cytokine from platelets on their activation. However, no previous study has implicated plasminogen in controlling
VEGF release by platelets. It has been found that the surface of activated platelets may serve as a matrix for plasminogen conversion into plasmin mediated mainly by internal urokinase-type activator (u-PA) exposed on the membranes [19]. Lys-plasminogen is converted to plasmin at a faster rate than Glu-form on the cell membrane [20]. Plasmin $(0.8 \mathrm{CU} / \mathrm{ml})$ has been shown to slowly cleave and activate low-affinity protease-activated receptor-4 (PAR-4) facilitating partial release of $\alpha$-granule content [21]. On the other hand, plasmin might reduce thrombin-induced signalling through desensitizing high-affinity receptor (PAR-1) [22]. So, both of these receptors can be partially cleaved by plasmin in a dose-dependent manner, thus suggesting a regulatory role of this proteinase in modulating platelet exocytosis. Likely, plasmin may affect GPVI-signalling, which is responsible for collagen-evoked platelet exocytosis [23]. Plasmin-mediated cleavage of VEGF significantly reduces its overall bioactivity (over 100-fold increase in $\mathrm{EC}_{50}$ ) [18]. Thus, it could be assumed that plasminogen/plasmin is responsible for limiting proangiogenic capacities of platelets through reducing 
the sensitivity of platelets to agonist-mediated signalling and facilitating VEGF cleavage.

Some authors have found that platelets constitutively generate angiostatins, internalize, store, and release them upon activation [24]. Plateletderived angiostatins are thought to counterbalance angiogenesis stimulatory effects, including VEGF signalling [25]. In our study, we confirmed that intact platelets are able not only to internalize, but also to produce angiostatins de novo, however, the ability to cleave plasminogen depends on platelet activation state. Platelets stimulated by thrombin or collagen have enhanced potential (at least, by 10 -folds) to convert plasminogen to angiostatins compared to quiescent cells. It has been earlier shown that MMPs are not largely involved in angiostatin generation by isolated platelet membranes [14]. Results of our inhibitory study with the use of p-NPGB confirm that plasmin may play a crucial role in plasminogen to angiostatin formation, but minor participation of other proteolytical activities cannot be neglected. Based on our own observations and above literature data, two-step mechanism of angiostatin generation by platelets can be proposed. At the first step, proenzyme molecules interact with platelet surface via binding to exposed receptors, and then converted into plasmin by means of u-PA (Lys-form converts faster than native protein). During the second step, active plasmin, being anchored to plasma membrane cleaves proenzyme molecules yielding angiostatins.

Among various candidates on the role of plasminogen/plasmin binding sites on the outer layer of platelet membrane, surface-exposed actin may be preferable. In the past study [9], we have shown that surface-exposed actin is involved in plasminogen binding to platelets, but the significance of this interaction has remained unrevealed yet. In the experiments with purified proteins, it has been shown that plasminogen/plasmin binds actin efficiently $\left(K_{\mathrm{d}} \sim 140 \mathrm{nMol} / \mathrm{l}\right)$ [12]. Of all plasminogen domains, kringle 5 (K5) is supposed to be responsible for binding actin. Therefore, cleavage of K5 during plasmin auto-proteolysis leads to the formation of angiostatin K1-4.5, which is released from the platelet membrane $[12,26]$. We showed that production of angiostatins in the presence of platelet membranes with actin, blocked by specific antibody, is significantly reduced. Therefore, surface-exposed actin can participate not only as a plasminogen receptor, but also provides a cell-surface-dependent mechanism for angiostatin generation by platelets. To our knowledge, several reports suggest the presence of a cell-surface actin form on other cell types. For example, surface-exposed $\beta$-actin on human cancer cell lines, such as PC-3 prostate, HT1080 fibrosarcoma, and MDA-MB231 breast cancer, mediates plasmin auto-proteolysis even in the absence of free sulfhydryl donors [12, 26, 27].

In conclusion, it could be postulated that the formation and functioning of the triple complex [activator - plasminogen/plasmin - actin] may represent a universal mechanism for the membrane-associated angiostatin formation. Collectively, obtained results significantly expand our knowledge on the regulatory role of plasminogen in platelet physiology. Lys-plasminogen (and native proenzyme, to a lesser extent) can be involved in the regulation of angiogenesis capacities of platelets via reducing agonistinduced VEGF release and serving as a substrate for angiostatin formation. Since platelets participate in the regulation of numerous angiogenesis-related physiological and pathological processes, including wound healing, cancer growth, cardiovascular events, inflammation, and others, the implication of plasminogen in such regulation may have a potential therapeutic significance.

Conflict of interest. Authors have completed the Unified Conflicts of Interest form at http://ukrbiochemjournal.org/wp-content/uploads/2018/12/ coi_disclosure.pdf and declare no conflict of interest.

\section{ПЛАЗМІНОГЕН МОДУЛЮЄ УТВОРЕННЯ ТА ВИВІЛЬНЕННЯ РЕГУЛЯТОРІВ АНГІОГЕНЕЗУ ТРОМБОЦИТАМИ}

\section{А. О. Тихомиров, Д. Д. Жерносеков, Т. В. Гриненко}

Інститут біохімії ім. О. В. Палладіна НАН України, Київ; e-mail: artem_tykhomyrov@ukr.net

Тромбоцити зберігають, утворюють та вивільняють велику кількість регуляторів ангіогенезу, які залучені як до репаративних процесів у тканинах у нормі, так і до розвитку патологій, асоційованих з ангіопатіями. Раніше було показано, що плазміноген регулює деякі функції тромбоцитів, однак його здатність модулювати їхні ангіогенні властивості досліджено недостатньо. Мета поданої роботи - визначити ефекти різних 
форм плазміногену на утворення та секрецію тромбоцитами протеїнів - регуляторів ангіогенезу. Відмиті тромбоцити людини одержували гель-фільтрацією на сефарозі-2В. Рівні експонованого Р-селектину (CD-62P) на плазматичній мембрані нестимульованих та активованих тромбоцитів вимірювали за допомогою протокової цитофлуориметрії. Секрецію фактора росту ендотеліоцитів судин (VEGF) тромбоцитарного походження, а також фрагментацію плазміногену та утворення ангіостатинів інтактними тромбоцитами та плазматичними мембранами тромбоцитів визначали за допомогою імуноблотингу. Показано, що за дії тромбіну або колагену збільшувалась кількість Р-селектину на поверхні тромбоцитів, тоді як Lys-форма плазміногену пригнічувала агоністіндуковану тромбоцитарну секрецію. Lys-плазміноген, але не Glu-форма, інгібував агоністіндуковане вивільнення VEGF із тромбоцитів. Активація тромбоцитів сприяла істотному підсиленню розщеплення плазміногену та утворенню ангіостатинів. Антитіла проти актину інгібували фрагментацію плазміногену за інкубації із плазматичними мембранами тромбоцитів, що вказує на роль поверхнево-експонованого актину в перетворенні плазміногену на ангіостатини. Дослідження демонструє нову функцію плазміногену, яка полягає в обмеженні ангіогенної активності тромбоцитів через утворення ангіостатинів та інгібування секреції фактора росту ендотеліоцитів.

К л ю ч о в і с л о в а: плазміноген, тромбоцити, ангіогенез, фактор росту ендотеліоцитів судин (VEGF), ангіостатини.

\section{References}

1. Wojtukiewicz MZ, Sierko E, Hempel D, Tucker SC, Honn KV. Platelets and cancer angiogenesis nexus. Cancer Metastasis Rev. 2017; 36(2): 249-262.

2. Di Vito C, Navone SE, Marfia G, Abdel Hadi L, Mancuso ME, Pecci A, Crisà FM, Berno V, Rampini P, Campanella R, Riboni L. Platelets from glioblastoma patients promote angiogenesis of tumor endothelial cells and exhibit increased VEGF content and release. Platelets. 2017; 28(6): 585-594.
3. Cao Y, Xue L. Angiostatin. Semin Thromb Hemost. 2004; 30(1): 83-93.

4. Dong Z, Kumar R, Yang X, Fidler IJ. Macrophagederived metalloelastase is responsible for the generation of angiostatin in Lewis lung carcinoma. Cell. 1997; 88(6): 801-810.

5. Jurasz P, Alonso D, Castro-Blanco S, Murad F, Radomski MW. Generation and role of angiostatin in human platelets. Blood. 2003; 102(9): 3217-3223.

6. Tykhomyrov AA. Interaction of actin with plasminogen/plasmin system: mechanisms and physiological role. Biopolym Cell. 2012; 28(6): 413-423.

7. Shin EK, Park H, Noh JY, Lim KM, Chung JH. Platelet shape changes and cytoskeleton dynamics as novel therapeutic targets for antithrombotic drugs. Biomol Ther (Seoul). 2017; 25(3): 223-230.

8. Tykhomyrov AA. Dynamics of thrombininduced exposition of actin on the platelet surface. Ukr Biochem J. 2014; 86(5): 74-81.

9. Tykhomyrov AA, Zhernossekov DD, Grinenko TV. Surface-exposed actin binds plasminogen on the membrane of agonistactivated platelets: a flow cytometry study. Biopolym Cell. 2017; 33(3): 172-182.

10. Tykhomyrov AO, Zhernosiekov DD, RokaMoya YM, Diordieva SI, Grinenko TV. Effects of Lys-form of plasminogen on platelet actin cytoskeleton. Fiziol Zh. 2014; 60(1): 25-33. (In Ukrainian).

11. Tykhomyrov AA, Zhernosekov DD, RokaMoya YM, Diordieva SI, Grinenko TV. The effects of Lys-plasminogen on human platelet secretion. Fiziol Zh. 2015; 61(6): 26-34. (In Ukrainian).

12. Wang H, Doll JA, Jiang K, Cundiff DL, Czarnecki JS, Wilson M, Ridge KM, Soff GA. Differential binding of plasminogen, plasmin, and angiostatin 4.5 to cell surface beta-actin: implications for cancer-mediated angiogenesis. Cancer Res. 2006; 66(14): 7211-7215.

13. Tykhomyrov AA, Yusova EI, Diordieva SI, Corsa VV, Grinenko TV. Production and characteristics of antibodies against K1-3 fragment of human plasminogen. Biotechnol Acta. 2013; 6(1): 86-96. 
14. Jurasz P, Santos-Martinez MJ, Radomska A, Radomski MW. Generation of platelet angiostatin mediated by urokinase plasminogen activator: effects on angiogenesis. J Thromb Haemost. 2006; 4(5): 1095-1106.

15. Ritchie JL, Alexander HD, Rea IM. Flow cytometry analysis of platelet P-selectin expression in whole blood - methodological considerations. Clin Lab Haematol. 2000; 22(6): 359-363.

16. Repsold L, Pool R, Karodia M, Tintinger G, Joubert AM. An overview of the role of platelets in angiogenesis, apoptosis and autophagy in chronic myeloid leukaemia. Cancer Cell Int. 2017; 17: 89.

17. Battinelli EM, Markens BA, Italiano JE Jr. Release of angiogenesis regulatory proteins from platelet alpha granules: modulation of physiologic and pathologic angiogenesis. Blood. 2011; 118(5): 1359-1369.

18. Vempati P, Popel AS, Mac Gabhann F. Extracellular regulation of VEGF: isoforms, proteolysis, and vascular patterning. Cytokine Growth Factor Rev. 2014; 25(1): 1-19.

19. Lenich C, Liu JN, Gurewich V. Thrombin stimulation of platelets induces plasminogen activation mediated by endogenous urokinasetype plasminogen activator. Blood. 1997; 90(9): 3579-3586.

20. Zhang L, Gong Y, Grella DK, Castellino FJ, Miles LA. Endogenous plasmin converts Glu-plasminogen to Lys-plasminogen on the monocytoid cell surface. J Thromb Haemost. 2003; 1(6): 1264-1270.

21. Quinton TM, Kim S, Derian CK, Jin J, Kunapuli SP. Plasmin-mediated activation of platelets occurs by cleavage of proteaseactivated receptor 4. J Biol Chem. 2004; 279(18): 18434-18439.

22. Kuliopulos A, Covic L, Seeley SK, Sheridan PJ, Helin J, Costello CE. Plasmin desensitization of the PAR1 thrombin receptor: kinetics, sites of truncation, and implications for thrombolytic therapy. Biochemistry. 1999; 38(14): 4572-4585.

23. Ollivier V, Syvannarath V, Gros A, Butt A, Loyau 1, Jandrot-Perrus M, Ho-Tin-Noé B. Collagen can selectively trigger a platelet secretory phenotype via glycoprotein VI. PLoS One. 2014; 9(8): e104712.

24. Radziwon-Balicka A, Moncada de la Rosa C, Zielnik B, Doroszko A, Jurasz P. Temporal and pharmacological characterization of angiostatin release and generation by human platelets: implications for endothelial cell migration. PLoS One. 2013; 8(3): e59281.

25. Radziwon-Balicka A, Ramer C, Moncada de la Rosa C, Zielnik-Drabik B, Jurasz P. Angiostatin inhibits endothelial MMP-2 and MMP-14 expression: a hypoxia specific mechanism of action. Vascul Pharmacol. 2013; 58(4): 280-291.

26. Wang H, Schultz R, Hong J, Cundiff DL, Jiang K, Soff GA. Cell surface-dependent generation of angiostatin4.5. Cancer Res. 2004; 64(1): 162168.

27. Özlü N, Qureshi MH, Toyoda Y, Renard BY, Mollaoglu G, Özkan NE, Bulbul S, Poser I, Timm W, Hyman AA, Mitchison TJ, Steen JA. Quantitative comparison of a human cancer cell surface proteome between interphase and mitosis. EMBO J. 2015; 34(2): 251-265. 